\title{
TEKNIK PENGEMBANGAN INDUSTRI EKOTOURISME KOTA BATU PROVINSI JAWA TIMUR DALAM PERSPEKTIF KEBIJAKAN
}

\author{
MOCH. AGUS KRISNO BUDIYANTO \\ Program Studi Pendidikan Biologi FKIP Universitas Muhammadiyah Malang \\ E-mail: aguskrisno@yahoo.co.id
}

\begin{abstract}
ABSTRAK
Hasil penelitian sebelumnya telah diperoleh tipologi pengembangan potensi ekotourisme di Kota Batu dan potensi ekotourisme wisata Cangar. Namun demikian belum diungkap lebih jauh pengembangan industri ekotourisme Kota Batu dalam perspektif kebijakan. Oleh karena itu penelitian ini bertujuan untuk menjelaskan pengembangan ekotourisme Kota Batu dalam perspektif kebijakan. Untuk mencapai tujuan tersebut maka fokus penelitian ini adalah pengembangan industri ekotourisme Kota Batu dalam perspektif kebijakan. Pendekatan penelitian yang digunakan dalam penelitian ini adalah penelitian kualitatif dengan desain penelitian Fenomenologi. Subyek penelitian adalah Badan Perencanaan Pembangunan dan Pengembangan Kota (Bappeko) Batu dan Dinas Pariwisata Kota Batu. Metode pengumpulan data yang digunakan adalah dokumentasi dan wawancara mendalam. Data penelitian yang diperoleh dianalisis dengan analisis kualitatif (content analysis) dengan menggunakan Interactive Model dari Miles and Huberman. Berdasarkan hasil penelitian, maka dapat dinyatakan bahwa pengembangan industri ekotourisme Kota Batu dalam perspektif kebijakan jika dikaji dari standar pengembangan potensi ekotourisme menurut indikator International Ecotourism Society dan Mader, sudah termasuk baik. Pengembangan industri ekotourisme melibatkan semua dinas di Kota Batu, dan juga meliputi semua aspek kehidupan yaitu aspek ekonomi, sosial budaya, politik, dan keamanan.
\end{abstract}

Kata kunci: industri ekotourisme, pengembangan teknis, perspektif kebijakan

\begin{abstract}
The previous researches, the typology development of Batu City ecotourism potency and ecotourism potency of Canggar. Nevertheless, the ecotourism development industries in Batu City based on policy perspective has not been explored further. For this reason, this research aims at finding the development of Batu City ecotourism in policy perspective. To achieve this aim, the scopes of this research is the ecotourism development industries in Batu City based on policy perspective. The design of research used in this research is qualitative research (fenomenologys). The subject is Planing and Development Office of Batu City and Tourism Office of Batu City. The data collection method used is documentation and indepth interview. The data was analyzed qualitatively (Content Analysis) by means of interactive model from Miles and Huberman. Based on the research finding the ecotourism development industries in Batu City bassed on policy perspective included The International Ecotourism Society and Mader is good. The ecotourism development industries involve all officials at Batu City, and also cover all life aspects that is economy aspect, social culture, policies, and security.
\end{abstract}

Keywords: ecotourism industries, technical development, policy perspective

\section{PENDAHULUAN}

World Tourism Organization (Boo, 2004) melaporkan adanya pergeseran pada orientasi industri wisata dari industri wisata konvensional menjadi industri ekotourisme. Di sisi lain menurut Budiyanto (2005) dan M. Syoim dan Fadli M (2004) penerapan otonomi daerah mendorong upaya pengembangan potensi daerah dalam rangka peningkatan pendapatan daerah untuk kesejahteraan masyarakat. Pengembangan potensi industri ekotourisme menjadi sebuah trend penggalian Pendapatan Asli Daerah
(PAD), termasuk Kota Batu yang mempunyai visi sebagai kota agropolitan bernuansa pariwisata.

Hasil penelitian terdahulu telah diperoleh tipologi pengembangan potensi ekotourisme di Kota Batu (Budiyanto, 2006), potensi ekotourisme wisata Cangar (Budiyanto,2005), namun demikian belum diungkap lebih jauh pengembangan industri ekotourisme Kota Batu. Dalam kontek Kota Batu sebagai Kota Agrowisata maka pengembangan industri ekotourisme menjadi strategis. Salah satu hal yang terus disempurnakan dalam upaya mendukung 
berkembangnya industri ekotourisme di Kota Batu adalah aspek kebijakan sebagai bentuk political will pemerintah dan masyarakat Kota Batu.

Berdasarkan uraian tersebut di atas, maka penelitian ini dirancang untuk menjawab masalah penelitian bagaimana pengembangan industri ekotourisme Kota Batu dalam perspektif kebijakan dengan sub masalah penelitian adalah bagaimana visi dan misi, arah kebijakan, konsep pengembangan, strategi pengembangan, dan program kerja pengembangan industri ekotourisme Kota Batu. Penelitian ini diharapkan menghasilkan konsep pengembangan industri ekotourisme Kota Batu dalam perspektif kebijakan. Perspektif kebijakan dikaji dari standar pengembangan potensi ekotourisme menurut International Ecotourism Society dan Mader.

\section{METODE}

Metode penelitian ini digambarkan pada Gambar 1 berikut.

Pendekatan riset yang digunakan dalam

INPUT

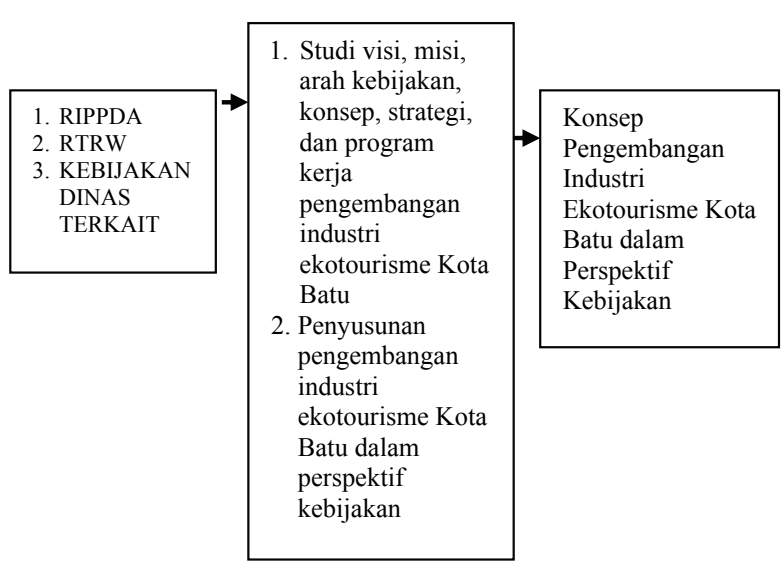

Gambar 1. Alur Penelitian Penyusunan Konsep Pengembangan Industri Ekotourisme Kota Batu dalam Perspektif Kebijakan

penelitian ini adalah penelitian kualitatif desain Fenomenologi dengan subyek penelitian meliputi Badan Perencanaan Pembangunan dan Pengembangan Kota (Bappeko) Kota Batu dan Dinas Pariwisata Kota Batu. Teknik sampling yang digunakan adalah purposive sampling. Fokus yang diteliti dalam penelitian ini adalah kebijakan pengembangan industri ekotourisme Kota Batu yang terdiri dari visi, misi, arah kebijakan, konsep pengembangan, strategi, dan program kerja pengembangan industri ekotourisme Kota Batu.

Data penelitian dikumpulkan dengan metode dokumentasi untuk data visi,misi, arah kebijakan, konsep, strategi, dan program kerja pengembangan ekotourisme Kota Batu dan wawancara mendalam untuk mendapatkan informasi kebijakan pengembangan industri ekotourisme Kota Batu yang tertuang dalam Rencana Induk Pengembanan Pariwisata Daerah (RIPPDA) Kota Batu dan Rencana Tata Ruang Wilayah (RTRW) Kota Batu. Sebelum dianalisis data diuji keabsahan datanya dengan menggunakan triangulasi.

Analisis data yang digunakan dalam penelitian ini adalah analisis kualitatif dengan cara analisis isi (content analysis). Analisis isi adalah suatu teknik yang sistematik untuk menganalisis makna pesan dan cara mengungkapkan pesan. Langkah yang dilakukan pada analisis isi dalam penelitian ini menggunakan interactive model dari Miles dan Huberman (Miles \& Huberman, 1994). Model ini mengandung 4 komponen yang saling berkaitan, yaitu: (1) Pengumpulan data; (2) Penyederhanaan atau reduksi data; (3) Penyajian data; (4) Penarikan; dan Pengujian atau verifikasi simpulan (Budiyanto, 2002).

\section{HASIL DAN PEMBAHASAN}

Kota Batu merupakan daerah yang giat mengembangkan industri ekotourismenya dalam upaya meningkatkan PAD, yang tercermin dalam RIPPDA (Rencana Induk Pengembangan Pariwisata Daerah). Pengembangan industri ekotourisme di Kota Batu dilakukan dengan terus menyempurnakan kebijakan yang menyangkut visi, misi, arah kebijakan, konsep, strategi, dan program kerja pengembangan ekotourisme (termasuk industrinya) Kota Batu. Menurut M. Syoim dan Fadli M (2004) paradigma otonomi daerah, sesungguhnya mengisyaratkan agar masyarakat di daerah bisa hidup mandiri, dapat memenuhi kesejahteraan, bisa menikmati pendidikan, serta mampu melakukan karya-karya produktif dengan kemampuannya sendiri, dengan demikian otonomi daerah memberikan suasana kondusif bagi pembangunan kepariwisataan daerah. Beberapa daerah telah mulai menginventarisasi, membina dan mengembangkan objek wisata daerahnya, selain juga mencoba berusaha untuk memprioritaskan anggaran kepariwisataan melalui APBD-nya. Di banyak negara, bahkan beberapa daerah di negeri kita mendapatkan kesuksesan pembangunan daerahnya dikarenakan mengembangkan potensi pariwisatanya. Oleh karena itulah daerah lain dalam era otonomi daerah perlu membenahi pariwisata untuk dijadikan andalan bagi perolehan PAD dan masyarakat. Menjual wisata daerah perlu diawali dengan upaya perbaikan dan pengembangan secara komprehensif agar pariwisata bisa menjadi model pendekatan bagi pembangunan daerah dalam 
mewujudkan kesejahteraan masyarakat.

Menurut Bappeko Batu (2002) dan Bappeko Batu (2003), visi pengembangan ekotourisme Kota Batu adalah Batu agropolitan bernuansa pariwisata dengan masyarakat madani. Misi pengembangan ekotourisme adalah 1) Mengelola sumber daya alam berbasis pada pertanian dan pariwisata yang berwawasan lingkungan; 2) Pengembangan sistem ekonomi kerakyatan yang selaras dengan berkembangnya dunia usaha melalui kemitraan usaha ekomoni lemah dengan industri pariwisata dan pertanian; 3) Perwujudan kehidupan sosial yang dinamis dan berkembangnya seni budaya serta olahraga untuk menunjang pariwisata daerah; 4) Perwujudan kelestarian lingkungan hidup dan terkendalinya tata ruang wilayah; 5) Perwujudan kemananan dan ketertiban masyarakat; dan 6) Perwujudan pemerintahan yang baik dan bersih (Good Governance). Dari visi dan misi tersebut dapat dinyatakan bahwa pariwisata merupakan sektor andalan pengembangan Kota Batu.

Temuan penelitian pengembangan Industri Ekotourisme Kota Batu perspektif kebijakan disajikan pada Tabel 1 berikut.

Arah kebijakan pengembangan industri ekotourisme Kota Batu adalah 1) Mendorong pertumbuhan investasi di sektor pertanian, pariwisata, industri kecil/kerajinan dan jasa perdagangan; 2) Mengembangkan dan menata agrowisata secara terpadu berbasis pada kelestarian lingkungan hidup; 3) Mensinergikan antara usaha ekonomi lemah, koperasi dengan dunia usaha

Tabel 1. Hal-hal terkaitPengembangan Industri Ekotourisme Kota Batu

\begin{tabular}{ll}
\hline \multicolumn{1}{c}{ Perihal yang Diteliti } & \multicolumn{1}{c}{ Hasil Penelitian } \\
\hline $\begin{array}{l}\text { Visi Pengembangan } \\
\text { Ekotourisme }\end{array}$ & Batu, Agropolitan Bernuansa Pariwisata dengan Masyarakat Madani \\
\hline Misi Pengembangan & 1. Mengelola sumber daya alam berbasis pada pertanian dan pariwisata yang berwawasan lingkungan. \\
$\begin{array}{l}\text { Ekotourisme (Termasuk } \\
\text { Industrinya) }\end{array}$ & $\begin{array}{l}\text { 2. Pengembangan sistem ekonomi kerakyatan yang selaras dengan berkembangnya dunia usaha melalui } \\
\text { kemitraan usaha ekonomi lemah dengan industri pariwisata dan pertanian }\end{array}$ \\
& $\begin{array}{l}\text { 3. Perwujudan kehidupan sosial yang dinamis dan berkembangnya seni budaya serta olahraga untuk } \\
\text { menunjang pariwisata daerah. }\end{array}$ \\
& $\begin{array}{l}\text { 4. Perwujudan kelestarian lingkungan hidup dan terkendalinya tata ruang wilayah. } \\
\text { 5. Perwujudan keamanan dan ketertiban masyarakat. } \\
\text { 6. Perwujudan pemerintahan yang baik dan bersih (Good Governance). }\end{array}$
\end{tabular}

Arah Kebijakan Pengembangan Ekotourisme (termasuk Industrinya)

\section{Bidang Ekonomi}

1. Mendorong pertumbuhan investasi di sektor pertanian, pariwisata, industri kecil/kerajinan dan jasa perdagangan.

2. Mengembangkan dan menata agrowisata secara terpadu berbasis pada kelestarian hidup.

3. Mensinergikan antara usaha ekonomi lemah, koperasi dengan dunia usaha (pariwisata).

4. Meningkatkan produksi pertanian dan mengembangkan produk unggulan sesuai dengan potensi wilayah.

5. Meningkatkan dan mengembangkan produk-produk lokal sesuai dengan standar mutu.

Bidang Pendidikan

1. Mengembangkan ilmu pengetahuan dan teknologi (IPTEK) di dalam menghadapi era globalisasi dan untuk mengelola potensi sumber daya alam pada pertanian dan pariwisata yang berwawasan lingkungan.

Bidang Pelayanan Masyarakat

1. Mengatur dan mengembangkan pelayanan transportasi terkait dengan pengembangan wilayah dan kemudahan distribusi barang dan jasa dalam kota maupun antar daerah sekitarnya dengan didukung sarana dan prasarana yang memadai.

2. Meningkatkan pelayanan prima pada fasilitas listrik dan komunikasi.

3. Mengembangkan dan meningkatkan pelayanan air bersih dengan mengoptimalkan pemanfaatan sumber air yang berwawasan.

Bidang Sosial dan Budaya

1. Mengembangkan kebebasan berkreasi dalam seni dan budaya daerah.

2. Mengembangkan kegiatan olahraga sebagai sarana mendorong pertumbuhan wisata olahraga.

Bidang Kelestarian Lingkungan Hidup dan Tata Ruang

1. Merehabilitasi dan mengendalikan kawasan hutan secara terpadu dan berbasis partisipasi masyarakat.

2. Penyusunan penataan ruang kawasan pertanian (agropolitan) dan kawasan wisata. 
Lanjutan Tabel 1.

\begin{tabular}{|c|c|}
\hline Perihal yang Diteliti & Hasil Penelitian \\
\hline \multirow[t]{5}{*}{$\begin{array}{l}\text { Konsep Pengembangan } \\
\text { Ekotourisme } \\
\text { (termasuk Industrinya) }\end{array}$} & $\begin{array}{l}\text { 1. Pengembangan objek-objek wisata potensial yang telah ada, seperti: Songgoriti, Jatim Park, } \\
\text { Agrokusuma, dan Wana Wisata Cangar dalam hal pengelolaan, pemeliharaan, penambahan sarana } \\
\text { dan prasarana, produk khas pertanian, pemberdayaan dan pelibatan masyarakat sekitar. }\end{array}$ \\
\hline & $\begin{array}{l}\text { 2. Pengembangan objek wisata potensial seperti Kolam Renang Banyu Urip, Wana Wisata Coban } \\
\text { Talun, Desa Wisata Sidomulyo, Wisata Husada, Goa-goa peninggalan sejarah, situs-situs bersejarah, } \\
\text { wisata olahraga paralayang, seni budaya tradisional, dan lain sebagainya dengan menyertakan } \\
\text { pengembangan potensi hasil-hasil pertanian dan pengayaan atraks wisata berwawasan lingkungan } \\
\text { dengan mempertahankan daya dukung lahan, sosial kemasyarakatan, dan tata ruang. }\end{array}$ \\
\hline & $\begin{array}{l}\text { 3. Peningkatan peran masyarakat, pelaku bisnis, dan pemerintah kota dengan program-program } \\
\text { sosialisasi, pelibatan aktif masyarakat, dan implementasi kebijakan-kebijakan Pemerintah Kota } \\
\text { berkaitan dengan kepariwisataan. }\end{array}$ \\
\hline & $\begin{array}{l}\text { 4. Peningkatan sarana dan prasarana penunjang (jalan, jembatan, komunikasi, air bersih, hotel, kolam } \\
\text { renang, pemancingan ikan, dan lain sebagainya), baik menuju dan dari objek wisata yang satu ke } \\
\text { objek wisata yang lain dan aksesibilitas menuju dan dari pusat kota menuju ke objek-objek wisata } \\
\text { yang ada. }\end{array}$ \\
\hline & $\begin{array}{l}\text { 5. Meningkatkan promosi dan pemasaran wisata melalui even-even khusus seperti pameran (expo), } \\
\text { festival kesenian tradisional, pertandingan olahraga berkelas internasional, dan lain sebagainya. }\end{array}$ \\
\hline
\end{tabular}

Strategi Pengembangan Ekotourisme (termasuk Industrinya)
1. Pengembangan objek dan daya tarik wisata eksisting (yang telah ada) dengan cara meningkatkan akses menuju objek wisata, daya tarik atau transaksi utama masing-masing objek wisata, diversifikasi dan kontinuitas penyelenggaraan aktivitas wisata, dan peran masyarakat sekitar.

2. Pengembangan objek dan daya tarik potensial, seperti objek Wisata Husada, Wisata Coban Talun, Wisata Paralayang, dan Wisata Pasar Senggol dengan cara mempermudah akses menuju lokasi objek wisata, mengembangkan fasilitas pendukung (kamar mandi/WC umum, sarana-prasarana ibadah, telekomunikasi, taman bermain, dan lain sebagainya), kontinuitas penyelenggaraan aktivitas wisata, dan peningkatan peran masyarakat.

3. Pengembangan usaha jasa pariwisata dengan cara menyelenggarakan Travel Exchange (Travex) secara periodik minimal satu tahun sekali, meningkatkan keikutsertaan dalam pasar wisata skala nasional maupun internasional terutama sebagai seller/produsen produk-produk wisata, menumbuhkembangkan iklim usaha dengan membuka peluang bisnis seluas-luasnya seperti biro perjalanan agen-agen tiket, jasa-jasa entertainment dan jasa impresariat (Even Organizer), membina kemitraan yang sejajar antara pemerintah dan masyarakat, dan meningkatkan jaringan kerjasama sektor pariwisata antara industri pariwisat, pemerintah, perusahaan perniagaan, dan ikatan profesional.

4. Menigkatkan pemasaran produk wisata melalui promosi wisata, pemantapan pasar wisata, pemantapan Pusat Pelayanan Informasi Pariwisata, dan meningkatkan kerjasama kepariwisataan.

5. Meningkatkan pelayanan untuk mendukung pengembangan kepariwisataan.

1. Pengembangan kawasan wisata yang berbasis pada alam, yaitu wisata rekreasi, wisata agro, wisata petualangan, wisata ilmu pengetahuan, wisata kesehatan, wisata olahraga dengan dilengkapi fasilitas dan infrastruktur wisata yang memadai.

Program Kerja

Pengembangan

Ekotourisme

(termasuk Industrinya)

2. Pengembangan wisata budaya pada hasil peninggalan bersejarah (candi, goa, bangunan kuno), atraksi kesenian tradisional dan industri kerajinan rakyat (gerabah, anyaman, alat-alat rumah tangga tradisional, kayu olahan, dan lain sebagainya).

3. Peningkatan SDM pariwisata dengan mengupayakan institusi pendidikan yang secara khusus dan profesional mampu menghasilkan SDM pariwisata, sistem ketenagaan yang berjenjang dalam bidang pariwisata, peningkatan kualitas masyarakat dalam industri jasa kepariwisataan.

4. Peningkatan investasi bidang pariwisata dengan cara menyediakan informasi kelayakan investasi daerah sektor pariwisata, penyebaran dan pemerataan investasi pada objek-objek wisata potensial, kemudahan dan fasilitas pendukung secara profesional kepada calon investor.

5. Pengembangan usaha jasa wisata akomodasi, restauran, biro perjalanan, money changer, dan lain sebagainya di kawasan wisata dan pusat pelayanan wisata di kawasan pusat kota.

6. Pengembangan promosi dan publikasi wisata di tingkat regional, nasional, dan internasional serta pengembangan kalender even wisata. (pariwisata); 4) Meningkatkan produksi pertanian dan mengembangkan produk unggulan sesuai dengan potensi wilayah; 5) Meningkatkan dan mengembangkan produk-produk lokal sesuai dengan standar mutu; 6) Mengatur dan mengembangkan pelayanan transportasi terkait dengan pengembangan wilayah dan kemudahan distribusi barang dan jasa dalam kota maupun antar daerah sekitarnya dengan didukung sarana dan prasarana yang memadai; dan 7) Meningkatkan pelayanan prima pada fasilitas listrik dan komunikasi.

Konsep pengembangan industri ekotourisme Kota Batu adalah: 1) Peningkatan sarana dan prasarana penunjang di kawasan wisata meliputi 
jalan, jembatan, komunikasi, air bersih, hotel, kolam renang, pemancingan ikan; 2) Meningkatkan promosi dan pemasaran wisata melalui even-even khusus seperti pameran, festival kesenian tradisional, pertandingan olahraga berkelas internasional; 3) Pengembangan objek-objek wisata potensial utama seperti Songgoriti, Jatim Park, Agrokusuma, dan Wana Wisata Canggar dalam hal pengelolaan, pemeliharaan, penambahan sarana prasarana, produk khas hasil pertanian; dan 4) Pengembangan objek wisata potensial lainnya seperti Kolam Renang Banyu Urip, Wana Wisata Coban Talun, Desa Wisata Sidomulyo, Wisata Husada, Goa-goa peningalan penjajah, situs-situs bersejarah, wisata olahgara paralayang, seni budaya tradisional dengan menyertakan pengembangan potensi hasil-hasil pertanian dan pengayaan atraksi wisata berwawasan lingkungan dengan memperhatikan daya dukung lahan, sosial kemasyarakatan, dan tata ruang.

Strategi pengembangan industri ekotourisme Kota Batu adalah 1) Pengembangan usaha jasa pariwisata dengan cara: menyelenggarakan Travel Exchange (Travex) secara periodik minimal satu tahun sekali, meningkatkan keikutsertaan dalam pasar wisata skala nasional maupun internasional terutama sebagai Seller/produsen produk-produk wisata, menumbuh-kembangkan iklim usaha dengan membuka peluang bisnis seluas-luasnya seperti biro perjalanan agen-agen tiket, jasa-jasa entertaimen, jasa impresariat (Even Organizer), membina kemitraan yang sejajar antara pemerintah dan masyarakat, dan meningkatkan jaringan kerjasama sektor pariwisata antara industri pariwisata, pemerintah, perusahaan perniagaan, dan ikatan profesional; 2) Meningkatkan pemasaran produk wisata melalui promosi wisata, pemantapan pasar wisata, pemantapan Pusat Pelayanan Informasi Pariwisata, dan meningkatkan kerjasama kepariwisataan; 3) Pengembangan objek dan daya tarik wisata eksisting (yang telah ada) dengan cara meningkatkan akses menuju objek wisata, penampilan atraksi utama masing-masing objek wisata, diversifikasi dan kontinuitas penyelenggaraaan aktivitas khusus; dan 4) Pengembangan objek dan daya tarik potensial seperti objek Wisata Husada, Wisata Coban Talun, Wisata Paralayang, Wisata Pasar Senggol dengan cara mempermudah akses menuju lokasi objek wisata, menyajikan spesifikasi atraksi wisata utama, mengembangkan fasilitas pendukung (meliputi kamar mandi/WC umum, sarana prasaran ibadah, telekomunikasi, taman bermain), kontinuitas penyelenggaraan aktivitas wisata, dan peningkatan peran masyarakat.

Program kerja pengembangan ekotourisme Kota Batu adalah: 1) Pengembangan kawasan wisata yang berbasis pada alam, yaitu wisata rekreasi, wisata agro, wisata petualangan, wisata ilmu pengetahuan, wisata kesehatan, wisata olahraga dengan dilengkapi fasilitas dan infrastruktur wisata yang memadai; 2) Pengembangan wisata budaya pada hasil peninggalan bersejarah (candi, goa, bangunan kuno), atraksi kesenian tradisional dan industri kerajinan rakyat misalnya gerabah, anyaman, alat-alat rumah tangga tradisional, kayu olahan; 3) Peningkatan sumber daya manusia pariwisata dengan mengupayakan: institusi pendidikan yang secara khusus dan profesional mampu menghasilkan sumber daya manusia pariwisata, sistem ketenagaan yang berjenjang dalam bidang pariwisata, peningkatan kualitas masyarakat dalam industri jasa kepariwisataan; 4) Peningkatan investasi bidang pariwisata dengan cara: menyediakan informasi kelayakan investasi daerah sektor pariwisata, penyebaran dan pemerataan investasi pada objekobjek wisata potensial, kemudahan dan fasilitas pendukung secara profesional kepada calon investor; 5) Pengembangan usaha jasa wisata akomodasi, restauran, biro perjalanan, money changer) di kawasan wisata dan di pusat pelayanan wisata yang ada di kawasan pusat kota; dan 6) Pengembangan promosi dan publikasi wisata di tingkat regional, nasional, dan internasional serta pengembangan kalender even wisata.

Pengembangan industri ekotourisme Kota Batu dalam perspektif kebijakan ternyata mengacu kepada standar pengembangan industri ekotourisme dunia menurut International Ecotourism Society dan Mader. Pengembangan industri ekotourisme berdasarkan indikator International Ecotourism Society dan Mader di Kota Batu sudah termasuk baik. Hal ini dikarenakan dari indikator pengembangan industri ekotourisme menurut International Ecotourism Society dan Mader, yang meliputi: 1) Keadaan fisik kawasan (luas, ketinggian, udara, topografi); 2) Potensi biotik kawasan (flora dan fauna); 3) Potensi produk dan olahan produk khas lokal; 4) Potensi wisata yang meliputi: a) wisata alam misalnya wisata dengan kegiatannya berupa hiking, berkemah, berkuda, bersepeda, b) wisata santai sambil berolahraga: misalnya tennis, berenang, lintas alam, c) wisata konvensi misalnya wisata sambil melakukan seminar, rapat, konferensi, d) wisata budaya misalnya berupa pergelaran seni tradisional; 5) Sarana prasarana seperti pembuatan pusat informasi, pondok kerja, sarana olahraga, coming ground, tempat bermain anak-anak, shelter, fasilitas penginapan, ruang pertemuan, kolam renang, tempat pemandaian, tempat camping, tempat pancing, kamar mandi umum, rumah makan atau warung, jalan, telekomunikasi, listrik, klinik, tempat 
ibadah, angkutan; 6) Aksestabilitas (kemudahan mencapai tempat wisata); 7) Partisipasi masyarakat (meaningful community participation); 8) Travel industry (tour companies, agency, and individual guides); 9) Media publikasi (writers, publishers, and public relation agencies); 10) Sumber daya manusia pengelola (academics, manager, environmentalists, security, and health) secara umum telah direncanakan dikembangkan dengan baik dalam perpektif kebijakan.

Ekotourisme menurut The Asian Ecotourism Society (2002) dalam Boo (2004) merupakan bentuk perjalanan wisata yang bertanggung jawab ke kawasan alami yang dilakukan dengan tujuan mengkonservasi lingkungan dan melestarikan kehidupan dan kesejahteraan penduduk setempat. Sedangkan menurut World Tourism Organization (WTO) dan United Nations Environment Program (UNEP) ekotourisme adalah suatu kegiatan wisata yang menitikberatkan keseimbangan antara menikmati keindahan alam dan upaya pelestarian lingkungan (alam dan budaya) dan meningkatkan partisipasi masyarakat dalam pengelolaannya. Penerapan ekotourisme yang benar, tidak saja akan mendatangkan devisa tetapi juga dapat mengeliminasi kerusakan lingkungan.

Menurut The International Ecotourism Society (2004) dan Anonymous (2009) ekotouisme adalah perjalanan yang bertanggung jawab di area alam dengan tujuan melestarikan lingkungan dan meningkatkan kesejahteraan penduduk setempat. Aktivitas ekotourisme meliputi beberapa prinsip yaitu: 1) Mengurangi dampak lingkungan; 2) Memberdayakan lingkungan alam dan budaya; 3) Meningkatkan pengalaman positif bagi wisatawan dan penduduk setempat; 4) Meningkatkan dana untuk kegiatan konservasi; 5) Meningkatkan dana untuk kegiatan pemberdayaan penduduk setempat; 6) Meningkatkan sensitivitas untuk kebijakan politik setempat, lingkungan, dan sosial; 7) Mendukung hak pekerja; dan 8) Fasilitasi pendidikan. Menurut Mader (2004) dari berbagai definisi tentang ekotourisme, maka ada 3 kriteia dalam ekotourisme yaitu: 1) Konservasi lingkungan (environmental conservation); 2) Partisipasi masyarakat (meaningful community participation); dan 3) Tujuan profit (profitable and can sustain itself).

Menurut Mader (2004) dan Anonymous (2008) pelayanan terhadap pelanggan ekotourisme dapat dilakukan dengan cara mengembangkan potensi ekotourisme dengan indikator sebagai berikut: 1) Lokasi (tempat tinggal permanen, pusat informasi, ruang tunggu tamu); 2) Transportasi (pesawat, bis, taksi, sepeda, kendaraan umum, mobil sewa), 3) Industri travel (perusahan wisata, agen wisata, pemandu wisata); 4) Tenaga promosi (penulis promosi, tenaga promosi, agen public relation); 5) Tenaga sektor sosial (tenaga akademik, ahli lingkungan, keamanan, tenaga kesehatan); dan 6) Potensi bukan manusia (binatang, tamaman, dan tempat).

Menurut The International Ecotourism Society (2004) dan Anonymous (2007) pelayanan terhadap pelanggan ekotourisme dapat dilakukan dengan cara mengembangkan potensi ekotourisme dengan indikator sebagai berikut: 1) Keadaan fisik kawasan (luas, ketinggian, udara); 2) Potensi biotik kawasan (flora fauna); 3) Potensi wisata yang meliputi: a) wisata alam dengan kegiatannya berupa hiking, berkemah, berkuda, bersepeda; wisata santai sambil berolahraga: tennis, berenang (air panas), lintas alam, b) wisata konvensi dengan kegiatan berupa wisata sambil melakukan seminar, rapat, konferensi; c) wisata budaya dengan kegiatan berupa pergelaran seni tradisional; 4) Sarana prasarana seperti pembuatan pusat informasi, pondok kerja, sarana olahraga, caming ground, tempat bermain anakanak, sarana pemandian air panas, shelter, fasilitas penginapan, tempat ibadah, ruang pertemuan, dan 5) Aksestabilitas (kemudahan mencapai tempat wisata).

\section{SIMPULAN}

Pengembangan industri ekotourisme Kota Batu dalam perspektif kebijakan dilakukan dengan menyempurnakan kebijakan pengembangan pariwisata Kota Batu dengan menggunakan standar pengembangan industri ekotourisme dunia. Pengembangan industri eotourisme tersebut tercermin dalam berbagai aspek kebijakan yaitu visi, misi, arah kebijakan, konsep pengembangan, strategi pengembangan, dan program kerja pengembangan ekotourisme. Pengembangan industri ekotourisme melibatkan semua dinas di Kota Batu, dan juga meliputi semua aspek kehidupan yaitu aspek ekonomi, sosial budaya, politik, dan keamanan.

Pengembangan industri ekotourisme berdasarkan indikator The International Ecotourism Society dan Mader di Kota Batu sudah termasuk baik. Hal ini dikarenakan dari indikator pengembangan industri ekotourisme menurut The International Ecotourism Society dan Mader secara umum telah direncanakan dikembangkan dengan baik dalam perpektif kebijakan. Dalam upaya mengembangkan industri ekotourisme Kota Batu, maka diperlukan koordinasi, kerja keras berbagai pihak untuk mengimplementasikan kebijakan pengembangan industri ekotourisme yang terdokumentasi dalam Rencana Induk Pengembangan Pariwisata Daerah (RIPPDA) Kota Batu dan Rencana Tata Ruang Wilayah (RTRW) Kota Batu. 


\section{DAFTAR PUSTAKA}

Anonymous, 2009. What is Ecotourism. The International Ecotourism Society. Washington DC: http://www. ecotourism.org. Diakses tanggal 07 Agustus 2009.

Anonymous 2008. Pengembangan Potensi Ekotourisme di Jawa Timur. Surabaya: Dinas Perkebunan dan Kehutanan Propinsi Jawa Timur. http://www. angelfire.com. Diakses tanggal 07 Agustus 2009.

Anonymous, 2007. Indikator Taman Wisata Alam Gunung Pancar. Bandung: Pemerintah Propinsi Jawa Barat.

Badan Perencanaan Pembangunan Kota Batu, 2003, Rencana Induk Pengembangan Pariwisata Daerah (RIPPDA) Kota Batu, Batu: Bappeko Batu.

Badan Perencanaan Pembangunan Kota Batu, 2002, Rencana Tata Ruang Wilayah (RTRW) Kota Batu, Batu: Bappeko Batu.

Budiyanto MAK, 2006. Tipologi Pengembangan Potensi Ekotourisme di Jawa Timur. Malang: Universitas Muhammadiyah Malang.
Budiyanto MAK, 2005. Studi Potensi Ekotourisme Wisata Canggar Batu. Malang: Universitas Muhammadiyah Malang.

Budiyanto MAK. 2002. Metodologi Penelitian. Malang: Universitas Muhammadiyah. Malang.

Boo E, 2004. Ecotourism: The Potential and Pifall. Washington DC.

Mader R, 2004. Exploring Ecotourism Resource Guide by Ron Mader. http://www.planeta.com. Global and Journal Practical Ecotourism. Diakses tanggal 25 Mei 2006.

Miles, M.B, Huberman, A.M, 1994, Qualitative Data Analysis, second edition, Sage Publication, New Delhi.

Syoim, M dan Fadli, M., 2004. Pembangunan Ekowisata di Kalimantan Timur. http://www.angelfire.com., Diakses tanggal 25 Mei 2006. 